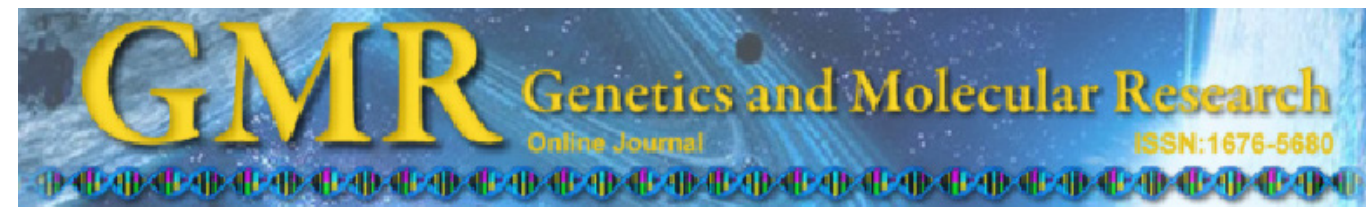

Short Communication

\title{
Polymorphisms of the myostatin gene (MSTN) and its relationship with growth traits in goat breeds
}

\author{
Z.J. Zhang ${ }^{1,2 *}$, Y.H. Ling ${ }^{1,2 *}$, L.J. Wang ${ }^{1,2}$, Y.F. Hang ${ }^{1,2}$, X.F. Guo ${ }^{1,2}$, \\ Y.H. Zhang ${ }^{1,2}$, J.P. Ding ${ }^{1,2}$ and X.R. Zhang, ${ }^{1,2}$ \\ ${ }^{1}$ College of Animal Science and Technology, \\ Anhui Agricultural University, Hefei, P.R. China \\ ${ }^{2}$ Local Animal Genetic Resources Conservation and Biobreeding Laboratory \\ of Anhui Province, Hefei, P.R. China \\ *These authors contributed equally to this study. \\ Corresponding author: X.R. Zhang \\ E-mail: zhangxiaorong01@163.com
}

Genet. Mol. Res. 12 (2): 965-971 (2013)

Received October 18, 2012

Accepted January 31, 2013

Published April 2, 2013

DOI http://dx.doi.org/10.4238/2013.April.2.12

\begin{abstract}
Mutations in the myostatin (MSTN) gene can inactivate its expression and result in a non-functional protein, which leads to dramatic muscularity and a "double-muscling" phenomenon in many species. Using gene sequencing and polymerase chain reaction-singlestrand conformation polymorphism methods, polymorphisms of the MSTN gene were investigated as a candidate marker for growth in 288 goats. The results showed 2 novel single nucleotide polymorphisms: DQ167575 g.197G $>$ A and 345A $>$ T. Three potential genotypes (AA, $\mathrm{AB}$, and $\mathrm{BB}$ ) of substitution $197 \mathrm{G}>\mathrm{A}$ in the $5^{\prime}$-untranslated region were detected in the 2 breeds. The polymorphism (CC and CD) of substitution $345 \mathrm{~A}>\mathrm{T}$ in exon I was segregated. The genetic diversity analysis revealed that Boer goat and Anhui white goat possessed intermediate genetic diversity in the P1 and P3 loci. Significant
\end{abstract}


associations between the genotypes of the P3 locus and body weight, body length, and body height were observed in Boer goat and Anhui white goat $(\mathrm{P}<0.05)$. It could be inferred that the $M S T N$ gene may be a major gene or linked to the major gene affecting the goat growth traits. The polymorphic site could be a molecular marker-assisted selection program for body weight.

Key words: Goat; Myostatin gene (MSTN); Polymorphism; PCR-SSCP; Growth traits

\section{INTRODUCTION}

Myostatin (MSTN) is a member of the transforming growth factor- $\beta$ superfamily, which plays an essential role in the regulation of muscle growth and meat quality (Zhang et al., 2012). The MSTN gene has 3 exons and 2 introns (Bellinge et al., 2005), and encodes a glycoprotein that is expressed widely in skeletal muscle. Changes in the gene structure and expression may regulate the expression of target genes, thereby changing the composition of muscle fibers and causing a variation of muscle weight (Chen, 2008). Meanwhile, some studies demonstrated that the MSTN gene inhibited MyoD activity and expression via Smad3, resulting in the failure of myoblasts to differentiate into myotubes. These studies demonstrated that the MSTN gene plays a critical role in myogenic differentiation (Jin, 2011).

Mutations in the MSTN gene can inactive its expression or produce a non-functional protein, which leads to dramatic muscularity and a "double-muscling" phenomenon in many species (Grisolia et al., 2009). At present, many scholars had done numerous researches in pigs and cattle (Walsh and Celeste, 2005; Fan et al., 2010). In sheep, mutations in the MSTN gene also had an important role in muscular development (Boman et al., 2009). As a consequence, the $M S T N$ gene is primarily responsible for muscle development and could be a potential candidate gene for animal muscle growth. However, similar investigations about the properties of the MSTN gene in goat breeds have been limited (Liu et al., 2006). Therefore, in this study, PCR-based single-strand conformation polymorphism (SSCP) and DNA sequencing were applied to detect single-nucleotide polymorphisms (SNPs) of the MSTN gene from 2 reference goat populations (Anhui white goat and Boer goat, which play an important role in the goat industry as the main meat goat breed in central China). These SNPs would provide molecular genetic material for studying the meat performance of goat.

\section{MATERIAL AND METHODS}

\section{Samples and DNA extraction}

Genomic DNA samples were obtained from 288 goats: Anhui white goat $(\mathrm{AH}, \mathrm{N}=$ 184 ) and Boer goat (BR, $\mathrm{N}=104)$, which were both reared at the Hefei Bo Da Livestock Technology Development Co., China, in 2011. Genomic DNA was extracted from all blood samples using a standard phenol-chloroform extraction method. 


\section{Primer synthesis and PCR}

Using the goat MSTN gene sequence (DQ167575), 3 pairs of primers were designed to amplify the 5'-untranslated region (UTR) and exon I fragments in the MSTN gene: P1 sense - 5'-CACAGATCCCGACGACAC-3' and P1 antisense - 5'-GGAAGAAGTAAGAACAAG -3'; P2 sense - 5'-CTTGTTCTTACTTCTTCC-3' and P2 antisense - 5'-ATCCTCAAGACT AGAAGCC-3'; P3 sense - 5'-GGCTTCTAGTCTTGAGTAC-3' and P1 antisense - 5'-CGAC TCTGCTGACTGCTGT-3'.

The PCRs were performed in a final volume of $20 \mu \mathrm{L}$, containing $2 \mu \mathrm{L}$ DNA template, $0.5 \mu \mathrm{L}$ each primer, $2.4 \mu \mathrm{L}$ dNTPs, $0.5 \mu \mathrm{L}$ Taq DNA polymerase, $2 \mu \mathrm{L} 10 \mathrm{X}$ reaction buffer, and $12.1 \mu \mathrm{L} \mathrm{ddH_{2 }} \mathrm{O}$. The PCR profile was 5 min at $95^{\circ} \mathrm{C}$, followed by 32 cycles of $30 \mathrm{~s}$ at $94^{\circ} \mathrm{C}$, $30 \mathrm{~s}$ at $56^{\circ} \mathrm{C}$, and $40 \mathrm{~s}$ at $72^{\circ} \mathrm{C}$, and a final extension of $10 \mathrm{~min}$ at $72^{\circ} \mathrm{C}$. The PCR products were stored at $4^{\circ} \mathrm{C}$ and were detected by $1 \%$ agarose gel electrophoresis.

\section{Detecting genetic variation}

The SSCP method was used to scan the mutations in the MSTN gene. Aliquots of $2 \mu \mathrm{L}$ PCR products were mixed with $8 \mu \mathrm{L}$ denaturing solution, heated for $10 \mathrm{~min}$ at $98^{\circ} \mathrm{C}$, and chilled in ice immediately for $7 \mathrm{~min}$. The denatured DNA was subjected to $10 \%$ PAGE analysis, which was run in $1 \mathrm{X}$ TBE buffer at $300 \mathrm{~V}$ for $30 \mathrm{~min}$, then at a constant $240 \mathrm{~V}$ for $30 \mathrm{~min}$, and finally at a constant $110 \mathrm{~V}$ for $12 \mathrm{~h}$. The gels were stained with $0.2 \%$ silver nitrate and visualized with $3 \% \mathrm{NaOH}$ solution. We took photographs of the results and recorded the genotypes (Jin et al., 2012).

\section{Haplotype sequencing and statistical analysis}

After the polymorphisms were detected, the PCR products of different electrophoresis patterns were selected for sequencing. The linear model with fixed effects was used to analyze the relationships between genotypes and growth traits of the 2 goat breeds. The linear model used was as follow: $Y_{\mathrm{ijk}}=\mu+\operatorname{Breed}_{\mathrm{i}}+\operatorname{Age}_{\mathrm{j}}+\operatorname{Marker}_{\mathrm{k}}+e_{\mathrm{ijk}}$, where $Y_{\mathrm{ijk}}$ is the observation of the trait, $\mu$ is the least-square mean, Breed is the effect of breed, Age $\mathrm{e}_{\mathrm{j}}$ is the effect of age, Marker ${ }_{\mathrm{k}}$ is the effect of marker genotype, and $e_{\mathrm{ijk}}$ is the residual effect.

\section{RESULTS}

\section{PCR amplification and SSCP detection}

Three pairs of primers in this study were designed to amplify the goat genomic DNA, and the quality of the PCR products was checked by electrophoresis on $1 \%$ agarose gel. The PCR products had a single and clear strip, without smearing, which were appropriate for PCR-SSCP analysis. Results of PCR-SSCP showed that three genotypes (AA, AB, and $\mathrm{BB}$ ) were present in the 5'-UTR, whereas only 2 genotypes (CC and CD) were detected in exon I. 


\section{Analysis of sequencing results}

The PCR products of different genotypes were cloned and sequenced. We found $2 \mathrm{mu}-$ tations located at 197 and $345 \mathrm{bp}$, respectively, by carrying out a BLAST search of goat MSTN gene sequences in GenBank (DQ167575). The substitution 197G>A was a synonymous mutation, which did not cause the mutation of amino acid. The substitution $345 \mathrm{~A}>\mathrm{T}$ CC genotype caused a variation of amino acid, compared with the CD genotype, as shown in Figure 1.
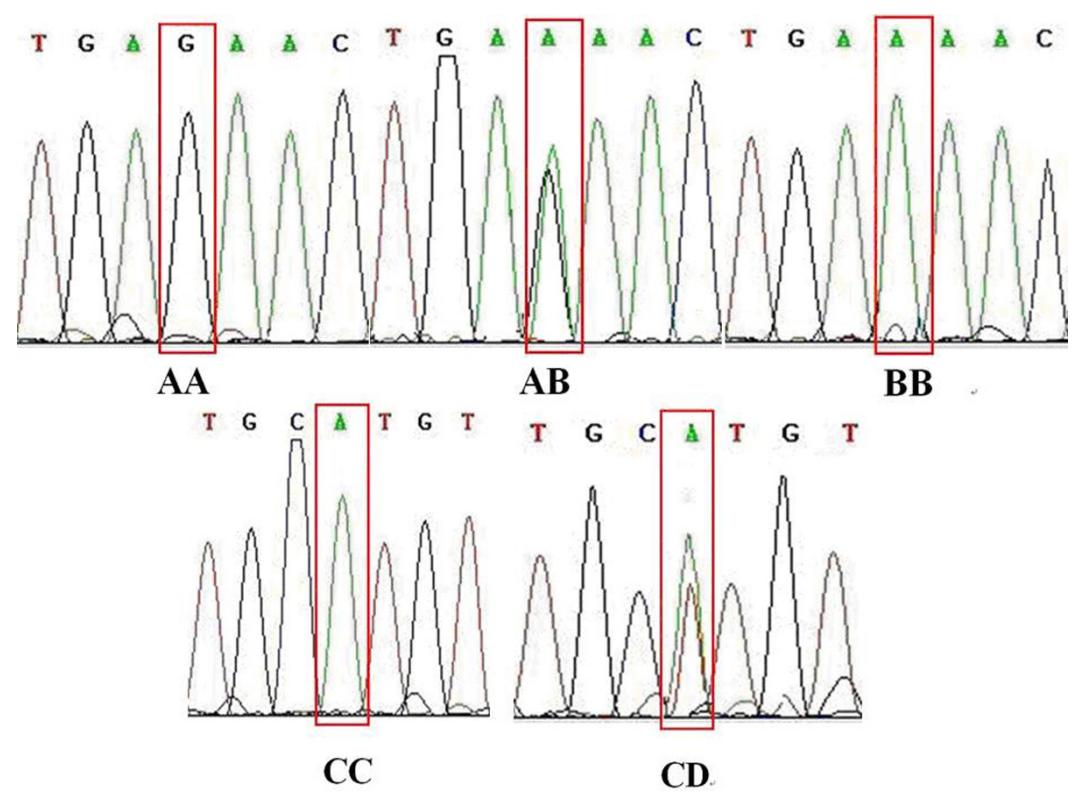

Figure 1. Sequence alignments of $\mathrm{AA}, \mathrm{AB}, \mathrm{BB}$ genotypes of primer $\mathrm{P} 1$, and $\mathrm{CC}$ and $\mathrm{CD}$ genotypes of primer $\mathrm{P} 3$ in the goat MSTN gene

\section{Genetic polymorphisms of the MSTN gene in different goat breeds}

The following conclusions were demonstrated by the chi-square test, and genotypic and allelic frequencies in the 2 different goat breeds. These genotypic results indicated that allele A was absolutely dominant in Anhui white goats, whereas allele B was the dominant allele in Boer goat populations. Genotype composition in BR goat: AA, 24.0\% (25); BB, 43.3\% (45); AB, 32.7\% (37). Genotype composition in AH goat: AA, 56.0\% (103); BB, 9.8\% (18); AB, 34.2\% (63). Genotype composition in BR goat: CC, 69.2\% (72); CD, 30.8\% (32). Genotype composition in AH goat: CC, $60.9 \%$ (112); CD, 39.1\% (72). These data are shown in Table 1.

\section{Association of genotypes in the MSTN gene with goat growth traits}

The genetic variations within 5'-UTR and exon I in the MSTN gene and the association between the genotypes and the growth traits (body weight, body height, body length, and chest circumference) in goat are shown in Table 1. It shows that there are significant associations 
between the genotypes of the P3 locus and body weight, body length, and body height in the $\mathrm{BR}$ and $\mathrm{AH}$ goats $(\mathrm{P}<0.05)$. BR goats with the $\mathrm{CC}$ genotype outperformed those with the CD genotype by approximately $2.12 \mathrm{~kg}$ in body weight, $1.38 \mathrm{~cm}$ in body height, and $1.88 \mathrm{~cm}$ in body length $(\mathrm{P}<0.05)$. Meanwhile, $\mathrm{AH}$ goats with the $\mathrm{CC}$ genotype outperformed those with the CD genotype by approximately $20.80 \mathrm{~kg}$ in body weight, $2.02 \mathrm{~cm}$ in body height, $2.58 \mathrm{~cm}$ in body length, and $2.05 \mathrm{~cm}$ in chest circumference $(\mathrm{P}<0.05)$. Moreover, there was a tendency for individuals with the BB genotype to have better performances in body height and body length than those with $\mathrm{AA}$ and $\mathrm{AB}$ genotypes, although no significant differences were apparent $(\mathrm{P}>0.05)$.

\begin{tabular}{|c|c|c|c|c|c|c|c|}
\hline \multirow[t]{2}{*}{ Loci } & \multirow[t]{2}{*}{ Breeds } & \multirow[t]{2}{*}{ GE } & \multirow[t]{2}{*}{ GF } & \multicolumn{4}{|c|}{ Growth traits (12 months) } \\
\hline & & & & Body weight & Body height & Body length & Chest circumference \\
\hline \multirow[t]{8}{*}{ P1 } & \multirow[t]{4}{*}{$\mathrm{BR}$} & AA & $24.0 \%(25)$ & $42.25 \pm 0.64$ & $71.78 \pm 0.25$ & $79.92 \pm 0.29$ & $88.41 \pm 0.37$ \\
\hline & & $\mathrm{AB}$ & $32.7 \%(34)$ & $41.36 \pm 0.27$ & $71.36 \pm 0.44$ & $79.44 \pm 0.51$ & $89.15 \pm 0.64$ \\
\hline & & $\mathrm{BB}$ & $43.3 \%(45)$ & $43.81 \pm 0.43$ & $70.00 \pm 1.73$ & $80.00 \pm 1.96$ & $87.50 \pm 2.51$ \\
\hline & & $\mathrm{P}$ & & $\mathrm{P}=0.411$ & $\mathrm{P}=0.45$ & $P=0.71$ & $\mathrm{P}=0.610$ \\
\hline & \multirow[t]{4}{*}{$\mathrm{AH}$} & AA & $56.0 \%(103)$ & $35.86 \pm 0.28$ & $65.00 \pm 1.07$ & $73.60 \pm 0.27$ & $85.58 \pm 0.31$ \\
\hline & & $\mathrm{AB}$ & $34.2 \%(56)$ & $36.96 \pm 0.32$ & $64.97 \pm 0.22$ & $71.90 \pm 1.43$ & $83.81 \pm 1.61$ \\
\hline & & $\mathrm{BB}$ & $9.8 \%(18)$ & $36.61 \pm 0.21$ & $64.56 \pm 0.32$ & $73.38 \pm 0.43$ & $85.70 \pm 0.49$ \\
\hline & & $\mathrm{P}$ & & $\mathrm{P}=0.342$ & $\mathrm{P}=0.562$ & $\mathrm{P}=0.470$ & $\mathrm{P}=0.871$ \\
\hline \multirow[t]{6}{*}{ P3 } & \multirow[t]{3}{*}{$\mathrm{BR}$} & $\mathrm{CC}$ & $69.2 \%(72)$ & $43.68 \pm 0.38^{\mathrm{A}}$ & $71.71 \pm 0.63^{\mathrm{A}}$ & $81.46 \pm 0.73^{\mathrm{a}}$ & $89.08 \pm 0.93$ \\
\hline & & $\mathrm{CD}$ & $30.8 \%(32)$ & $41.56 \pm 0.29^{\mathrm{B}}$ & $70.33 \pm 0.22^{\mathrm{B}}$ & $79.58 \pm 0.26^{\mathrm{b}}$ & $88.47 \pm 0.33$ \\
\hline & & $P$ & & $P=0.007$ & $\mathrm{P}=0.000$ & $\mathrm{P}=0.021$ & $\mathrm{P}=0.480$ \\
\hline & \multirow{3}{*}{$\mathrm{AH}$} & $\mathrm{CC}$ & $60.9 \%(112)$ & $36.86 \pm 0.32^{\mathrm{A}}$ & $66.73 \pm 0.51^{\mathrm{a}}$ & $76.80 \pm 0.67^{\mathrm{A}}$ & $87.52 \pm 0.78^{\mathrm{a}}$ \\
\hline & & $\mathrm{CD}$ & $39.1 \%(72)$ & $36.06 \pm 0.21^{\mathrm{B}}$ & $64.71 \pm 0.18^{\mathrm{b}}$ & $74.22 \pm 0.24^{\mathrm{B}}$ & $85.47 \pm 0.27^{\mathrm{b}}$ \\
\hline & & $\mathrm{P}$ & & $\mathrm{P}=0.003$ & $\mathrm{P}=0.013$ & $\mathrm{P}=0.000$ & $\mathrm{P}=0.035$ \\
\hline
\end{tabular}

$\mathrm{GE}=$ genotype $\mathrm{GF}=$ genotype frequency; $\mathrm{SE}=$ standard error of the mean. Means followed by small case superscript letters differ significantly at $\mathrm{P}<0.05$. Means followed by capital superscript letters differ significantly at $\mathrm{P}<0.01$.

\section{DISCUSSION}

The main determinants of fast growth in mammals are the increases of muscle cell growth and proliferation. Myostatin is a negative growth factor that inhibits both the terminal differentiation of myoblasts and the proliferation of myogenic cells (Thomas et al., 2000; Wiener et al., 2009). Our study focused on the identification of possible genetic variations of the MSTN gene and an evaluation of their genetic effects on goat production traits.

In the animal industry, the growth traits of animals, which are regulated by many genes, are always of primary concern during breeding for determining the animal's economical value (Chen et al., 2012). Generally, identifying genetic markers for growth traits is the initial and critical condition to establishing a marker-assisted selection system (Li et al., 2009). The gene sequence and its variations are the entry point to studying gene expression and function. In the latest study, the polymorphisms of the MSTN gene were shown to have a significant difference in different goat breeds. It was reported that the TTTTA deletion phenomenon of the MSTN gene had emerged in different species and might be unique for goats, compared with sheep, cattle, water buffalo, domestic yak, pigs, and humans (Hadjipavlou et al., 2008; Grisolia et al., 2009; Zhang et al., 2012).

Moreover, the diversity of the nucleic acid is a historical indicator of different goat 
breeds, so the polymorphism distribution is beneficial to study the population relationship. The polymorphisms of the MSTN gene have important implications on growth performance in 3 goat breeds. Li et al. (2008) found an important effect of a 5-bp deletion on goat early body weight and sizes, and that the heterozygote populations have better growth traits than homozygotes.

In this study, the genetic diversity analysis revealed that $\mathrm{BR}$ and $\mathrm{AH}$ goats possessed intermediate genetic diversity in the P1 and P3 loci. No mutation information was detected in the P2 locus. In the P1 locus, no significant associations were detected between any variant sites and body length, body height, and chest circumference $(\mathrm{P}>0.05)$. However, significant associations between the genotypes of the $\mathrm{P} 3$ locus and body weight, body length, and body height were observed in $\mathrm{AH}$ and BR goats $(\mathrm{P}<0.05)$. Furthermore, we suggest that the CC genotype in the MSTN gene could be regarded as a molecular marker for superior body weight. However, these results should be further investigated before they are used in goat breeding and genetics.

These results indicate that the MSTN gene is a candidate gene for goat growth performance, and plays a significant role in the body weight of goats $(\mathrm{P}<0.05)$. It could be inferred that the MSTN gene may be a major gene or linked to the major gene affecting goat growth traits. The polymorphic site could be a molecular marker-assisted selection program for body weight.

\section{ACKNOWLEDGMENTS}

Research supported by the National High Technology Research and Development (\#863) in China (\#SQ2010AA1000688008), the Anhui Natural Science Fund (\#1308085QC54), the Anhui Science Technology Program (\#11010302108), and Special Research Project of Public Service Sectors (Agriculture) (\#201303145).

\section{REFERENCES}

Bellinge RH, Liberles DA, Iaschi SP, O'Brien PA, et al. (2005). Myostatin and its implications on animal breeding: a review. Anim. Genet. 36: 1-6.

Boman IA, Klemetsdal G, Blichfeldt T, Nafstad O, et al. (2009). A frameshift mutation in the coding region of the myostatin gene (MSTN) affects carcass conformation and fatness in Norwegian White Sheep (Ovis aries). Anim. Genet. 40: 418-422.

Chen HQ, Qin J, Zhu YJ and Pan ZT (2012). The polymorphisms of goat thrsp gene associated with ecological factors in Chinese indigenous goat breeds with different lipogenesis ability. Asian J. Anim. Vet. Adv. 7: 802-811.

Chen TT (2008). Polymorphisms of MSTN, IGFBP-3 Gene and the Related Research with Growth Performance of Tianfu Goat, Sichuan Agricultural University, Ya'an.

Fan B, Lkhagvadorj S, Cai W, Young J, et al. (2010). Identification of genetic markers associated with residual feed intake and meat quality traits in the pig. Meat Sci. 84: 645-650.

Grisolia AB, D'Angelo GT, Porto Neto LR, Siqueira F, et al. (2009). Myostatin (GDF8) single nucleotide polymorphisms in Nellore cattle. Genet. Mol. Res. 8: 822-830.

Hadjipavlou G, Matika O, Clop A and Bishop SC (2008). Two single nucleotide polymorphisms in the myostatin (GDF8) gene have significant association with muscle depth of commercial Charollais sheep. Anim. Genet. 39: 346-353.

Jin H, Chen HQ, Q J and Zhu YJ (2012). The polymorphism in 5' regulatory region and exon 13 of PRKAG3 gene and its distribution pattern in different goat breeds. Asian J. Anim. Vet. Adv. 7: 568-577.

Jin XY (2011). Cloning and bioinformatics analysis on Myostatin (MSTN) gene of goat. China Anim. Husbandry Vet. Med. 38: 111-114.

Li XL, Liu ZZ, Zhou RY and Zheng GR (2008). Deletion of TTTTA in 5'UTR of goat MSTN gene and its distribution in 
different population groups and genetic effect on bodyweight at different ages. Front. Agric. China 2: 109.

Li YL, Zhang H, Zhang Q and Wang QL (2009). Research on the efficiency of marker-assisted selection in pig breeding system. China Anim. Husbandry Vet. Med. 36: 67-71.

Liu ZT, Li XL, Gong YF and Jin XM (2006). Relationship between polymorphism of goat MSTN gene intron 2 and body weight. Acta Vet. Zootech. Sin. 37: 745-748.

Thomas M, Langley B, Berry C, Sharma M, et al. (2000). Myostatin, a negative regulator of muscle growth, functions by inhibiting myoblast proliferation. J. Biol. Chem. 275: 40235-40243.

Walsh FS and Celeste AJ (2005). Myostatin: a modulator of skeletal-muscle stem cells. Biochem. Soc. Trans. 33: 15131517.

Wiener P, Woolliams JA, Frank-Lawale A, Ryan M, et al. (2009). The effects of a mutation in the myostatin gene on meat and carcass quality. Meat Sci. 83: 127-134.

Zhang C, Liu Y, Xu D, Wen Q, et al. (2012). Polymorphisms of myostatin gene (MSTN) in four goat breeds and their effects on Boer goat growth performance. Mol. Biol. Rep. 39: 3081-3087. 